\title{
Forced Flexibility and Exploitation: Experiences of Migrant Workers in the Cleaning Industry
}

I Natalia Ollus'

Senior Programme Officer, European Institute for Crime Prevention and Control, affiliated with the United Nations (HEUNI), Finland; Doctoral Candidate, Faculty of Law, University of Turku, Finland

\begin{abstract}
Globalization has resulted in structural changes in the labor markets over the last decades. These changes have weakened some of the economic and social dimensions of work. At the same time, migration and especially labor migration have increased on the global level. This article looks at the situation of migrant workers in the cleaning industry in Finland. It is based on interviews with migrant workers who have experienced labor exploitation in the cleaning industry, representatives of cleaning industry employers, and representatives of labor unions. The primary aim is to give voice to the migrant workers themselves and to analyze how they experience their work and their position in working life. The findings suggest that there is a risk that migrant workers in the cleaning sector experience various forms of exploitation. This article argues that the demand and need for (employee) flexibility may turn into forced flexibility that exploits the powerless and vulnerable migrant workers who have few other options than to agree to work on poor terms. The article suggests that the structural reasons that make the exploitation of migrant labor possible should be identified and addressed in order to prevent misuse of any workers, especially migrants.
\end{abstract}

\section{KEY WORDS}

Cleaning work / exploitation / globalization / human trafficking / migration.

DOI

10.19154/njwls.v6il.4908

\section{Introduction}

he cleaning industry is one example of a labor sector where the conditions of work have been particularly affected by forces of globalization and what may be defined as the effects of neoliberal policies (Bernstein 1986; Herod and Aguiar 2006). The demands for cost-effectiveness have led to increased competition, outsourcing, and subcontracting. As a result, work in the cleaning industry has changed from mostly permanent employment to increasingly flexible and temporary jobs. Flexible staffing arrangements are generally used by employers to minimize costs (Houseman 2001). Many of the effects of globalization seem to be less positive for those actually doing the work, the cleaners (Ryan and Herod 2006; Seifert and Messing 2006). Cleaning is inherently a form of low-skilled and low-paid employment (Öhrling 2014; Tarkkonen 2010). As a result a high share of those who work as cleaners today are migrants, whose possibilities

${ }^{1}$ E-mail: natalia.ollus@om.fi 
of accessing other jobs are limited due to their lack of language skills and contacts, their immigration status, and, in some cases, their lack of education (Abbasian and Hellgren 2012; Könönen 2012). Many migrant workers are multiply disadvantaged in the labor market also in Finland (Forsander 2013). This may make them particularly vulnerable to the negative effects of the structural changes in the labor market. With increased competition, some employers will attempt to cut costs through infringement of the rights of workers. It is evident that those who are the most powerless will be the most severely affected by such transgressions of labor rights and standards.

This article focuses on the experiences of migrant workers within the cleaning industry in Finland. The article draws on interviews with migrant workers, and interviews with representatives of employers and the trade union for the service sector. Although different actors have been interviewed, this article gives voice in particular to the migrant workers themselves. When talking about their experiences of working as cleaners in Finland, the migrant workers gave accounts of hard work on poor terms and also of exploitation and misuse. The employers, on the other hand, spoke of having no choice but to submit to the fierce competition in the sector, while trade unions criticized the employers for exploiting the most vulnerable and powerless of workers.

It is evident that the structural changes in the cleaning industry-such as increased competition, the disappearance of permanent jobs, privatization, and segmentationplay out in different ways for employers vis-à-vis employees. Building on an analysis of the interviews with migrant employees, trade unions, and some employers, this article seeks to answer two specific questions: How do migrant workers experience their working conditions in the cleaning industry in Finland? What kinds of labor market practices make migrant workers vulnerable to exploitation in the cleaning industry? In seeking an answer to these questions, this article discusses the experiences of migrant workers from their point of view. The central concepts in this article are flexibility, vulnerability, and exploitation. The article links exploitation with globalization and structural changes in the labor market, which have led to a situation where the demand for flexibility on behalf of the workers disproportionately affects the most powerless. These workers are often migrants with few other options than to accept work on disadvantageous terms. This article further shows that various misuses of migrant workers are related to more serious forms of exploitation, including, at worst, trafficking in human beings. Although all exploitation is of course not equivalent to trafficking, the difference between 'mere' exploitation and trafficking is fluid.

\section{Labor market policies and labor market changes}

The Finnish labor market is characterized by a tripartite bargaining structure, bringing together government, trade unions, and employers' organizations. There is no general minimum wage in Finland. Instead, the sector-specific agreements determine the minimum wage for each sector. The collective agreements apply also to unorganized workers, including migrant workers. The tripartite structure and industrial relations in general have been closely connected to the welfare state (Kettunen 2012). However, over the last 30 years the nature of work also in Finland has started to change, with increased competition and more demands for flexibility, with migrant workers becoming increasingly excluded from the labor and social policies of the welfare state (Lillie and Greer 
2007). At the same time, numerous research show that since the 1990s, the welfare state in Finland and its social programs have been weakened, thus creating more inequality in society (Jutila 2011; Kantola 2015; Riihinen 2011).

Economies and societies around the world have been affected by what can be defined as globalization and the expansion of neoliberal idea(l)s. Whether neoliberalism as such is directly applicable to the Nordic countries and Finland can be discussed, although Patomäki (2007) argues that neoliberalism entered Finland already with the opening of the financial markets in the 1980s. In his view, when the recession hit Finland in the early 1990s, neoliberalism was already a leading ideology (ibid., p. 55). Although a full neoliberal transformation of European welfare states has not (yet) taken place, the welfare state, also in Finland, has undergone many market-based reforms (Julkunen 2003, pp. 183-184). A major paradigmatic shift took place in the 1990s when Finland assumed the Washington consensus and, through justifications based on economic equilibrium, made significant cuts to its public sector (Böckerman and Kiander 2006; Riihinen 2011, pp. 126-127). Whether these developments were the result of neoliberalism per se is yet to be analyzed, but there has been a clear change of course of social policies in Finland since the 1990s (Riihinen 2011, p. 127).

These changes have affected the labor markets and thus the economic and social dimensions of work. The effects of globalization include intensified competition between companies as well as between countries. Stone argues that as a result of globalization, both businesses and states engage in actions that weaken labor rights (Stone 2005). Ylhäinen (2015) claims that while labor law has traditionally protected the rights of workers from employers' use of power, there is now-at least in the Finnish context-a rival discourse that represents the employer as the 'victim' of insecure economic and business conditions. Employers are seen to be at the mercy of fluctuating conditions beyond their control, and are therefore not wielding power in the way traditional labor law assumes. Ylhäinen finds that the employee, in turn, is seen as an autonomous, responsible subject instead of as an object in need of protection (ibid.). Such changes reflect a symbolic order of power, where the economy is given precedence before the rights of people (ibid.). Beck argues that labor market flexibility is the new political mantra that transfers risk from the state and the economy to the individual, with jobs becoming short term and easily terminable as a result (Beck 2000, p. 3; see Lambert 2008). It is evident that all of the consequences of increased labor flexibility have not only been positive, especially for those at the periphery of the labor market. The readiness to accept fragmentation in the nature of work is very different for those lower down the flexible regime (Sennett 1998, pp. 62-63).

\section{The vulnerabilities of migrant workers}

Finland has a relatively small share of migrants overall, and thus migrants form a relatively small share of the labor force. In 2014, there were a total of 144,000 foreignborn workers in Finland, making up $6 \%$ of the total labor force (Sutela 2015). While migrants represent a diverse group of people, there were proportionately more migrants working as cleaners and domestic workers (23\% of all cleaners were migrants in 2014), followed by assisting positions in restaurants and catering (18\%) compared to their share of the total working population (ibid.). Migrants are more often than 
Finnish-born workers working in temporary or part-time positions, and working atypical hours (ibid.). Also agency work is more common among foreign-born workers as is underemployment, that is, not having as much work as one would wish (ibid.). Migrant workers in Finland thus find themselves at the nexus of the segmentation and dualization of the labor market. Although the dual labor-market model (Piore 1979) may no longer fully reflect the multiplicity of the current labor markets, the division of the labor market is still valid in Finland (Forsander 2013), as recent statistics also show (Sutela 2015). Employment relations differentiate workers through various practices such as subcontracting, temporary employment, and casual employment, but also through a division based on personal traits such as gender, race, or ethnicity (Castles 2011; Lillie and Greer 2007).

Vulnerability is created both through belonging to a certain group and through circumstances (Honkatukia 2011). Vulnerability can increase over time, and is therefore not a clear-cut categorization, but instead forms a continuum and is bound to circumstances (ibid.). It is not just the migrant workers' immigration status and the lack of contacts and language skills (Abbasian and Hellgren 2012) that create vulnerability, but also the labor market and societal structures in which the migrant workers live and work. Gray argues that migrants tend to get the worst casual jobs because they are the most disadvantaged workers with the least bargaining power, and thus they get the jobs that are disproportionally part-time and temporary, and where wages increase more slowly than in other jobs $(2004$, p. 122). The position of migrant workers in the labor market is affected by both personal and structural factors. Both types of factors may make workers vulnerable. As immigrants, with for example a lack of skills (language, education) and lack of contacts and resources, migrant workers are disadvantaged in the labor market (Forsander 2013). In addition, structural inequalities, such as racialization and social stigmatization (Gomberg-Muñoz 2010), increase migrant workers' vulnerabilities, making them doubly stigmatized.

\section{Cleaning work in Finland}

In 2011, the over 6,000 cleaning companies in Finland employed almost 60,000 persons (Verohallinto (Tax Administration) 2013, p. 2). Although most of the companies (70\%) are small one-person enterprises, the large shareholder companies account for $85 \%$ of the total turnover in the sector (ibid.). The cleaning industry offers one of the most common entry-level jobs for migrants coming to Finland (ibid.). According to recent statistics, almost $40 \%$ of all workers in the cleaning industry in the greater Helsinki region are migrants (Myrskylä and Pyykkönen 2015). According to statistics by the Service Union United (SUU), almost half of the workers in the cleaning industry have an atypical contract (personal communication with a representative of the SUU, 14 December 2015). The number of part-time cleaning workers increased by one-fifth between 2013 and 2014 (ibid.). ${ }^{1}$

The cleaning industry is one example of the labor market that has undergone specific structural changes as a result of globalization (Herod and Aguiar 2006). Such changes have been ongoing already since the 1980s (Bernstein 1986). These changes have led to increased competition and demands for flexibility. The increasing employment precariousness among cleaning workers has been affected precisely by practices of outsourcing, 
work intensification, the privatization of government services, and deregulation (Ryan and Herod 2006). Because cleaning work cannot be exported to countries with cheaper labor costs, it has instead become outsourced to specialized cleaning companies. Paradoxically, the move toward specialization and 'professionalization' (Herod and Aguiar 2006; Verohallinto (Tax Administration) 2013) does not translate into an increase in the status of cleaning work. Cleaning work has on the one hand become more technical and thus work can be carried out more efficiently, but on the other hand there is less time allocated to performing the same work as before, placing increased strain on the workers (Tarkkonen 2010).

The cleaning industry is a crowded field, with many firms competing for the same bids, creating competition through price-setting, rather than through quality of service (Abbasian and Hellgren 2012). In a Finnish study of the cleaning industry, cleaning companies themselves were critical of the fact that the price is given too much weight when selecting bids (Lith 2012). When employers and clients alike seek the best deals, the workers bear the consequences. The lowest bid often wins tenders, resulting in poor quality cleaning services and also bad wages and working conditions for cleaners (Abbasian and Hellgren 2012). Employers evade responsibility for the results of the competition by placing the blame on those who buy the cleaning service, while the representatives of the employees place the blame on the greed of the companies (Ollus and Jokinen 2013). All in all, this creates the possibility for transgressions and misuse of labor in the cleaning industry.

\section{Exploitation of migrant labor and labor trafficking}

The exploitation of migrant workers/labor refers to any form of misuse of or illegal acts against persons of foreign origin who are working in Finland. Both less serious and more serious acts are included within the term 'exploitation.' For instance, less serious forms of misuse of migrant workers could include paying migrant workers a marginally lower salary than Finnish workers. The crime of extortionate work discrimination (Criminal Code 47(3)) refers to situations where migrant workers are exploited, for example, based on their economically difficult situation, their dependence on the employer, or their lack of understanding of their rights in Finland. More serious forms of exploitation might include the use of force or threats against workers in order to ensure their compliance. In legal terms, more serious forms of exploitation of migrant workers may constitute the crime of trafficking in human beings (Criminal Code 25(3), 25(3a)). For example, a situation where someone abuses a victim's vulnerabilities, and imposes control over the victim, thus forcing this person to continue working, may be deemed an act of trafficking. It does not necessarily have to entail any movement over borders, or involve any organized criminal groups.

The elements of the crime of extortionate work discrimination partly overlap with the criminal provision on trafficking in human beings. Legal scholars have emphasized that extortionate work discrimination resembles human trafficking if the employee performs the work in inhumane conditions or without regard for work safety (Nuutila and Melander 2008, p. 1279). In practice, the distinction between the two provisions remains unclear and difficult for criminal justice practitioners to interpret (Roth 2010). Previous research shows that situations of exploitation 
of migrant labor in Finland, including in the cleaning industry, display features of human trafficking for forced labor, but it is difficult to identify trafficking (Jokinen et al. 2011; Ollus and Jokinen 2013; Roth 2010; Sams and Sorjanen 2015). The difference between less and more serious forms of exploitation, such as trafficking, is therefore not clear-cut.

The exploitation of migrant workers can be visualized as a continuum, ranging from less severe acts and situations all the way to very serious acts, such as forced labor and trafficking (Andrees 2008; David 2010). The worst forms of exploitation can be seen to fulfill the elements of human trafficking (Jokinen et al. 2011). Trafficking in human beings for the purpose of labor exploitation therefore can be understood to take place in the context of overall exploitation of migrant labor. While not all migrants working in the cleaning industry are victims of exploitation or trafficking, it is important to pay attention to labor market practices and structures that enable such exploitation. The exploitation of migrant workers takes place within the regular dynamics of the labor market, and in mainstream economic sectors (Andrees 2008). The exploitation of migrant labor is not an isolated phenomenon. Instead, it is closely linked to the segmentation, casualization, and deregulation of labor markets.

The phenomenon of exploitation of migrant labor and labor trafficking has been increasingly researched in recent years, and the forms of exploitation in the European context are rather well documented. The exploitation seems to involve certain similar traits despite it taking place in different geographical locations. Migrant workers have, for example, experienced excessive and irregular working hours, underpayment of wages, nonpayment of compensation for overtime or weekend work, control and isolation, poor living conditions, the charging of illegal recruitment or other fees, deception regarding the contracts, terms of employment, and work permits, abuse of their lack of awareness of rights and alternatives, threats of dismissal and deportation, and even the threat or use of direct violence, including sexual violence (Allamby et al. 2011; Andrees 2008; Anti-Slavery International 2006; Clark 2013; FRA 2015; Geddes et al. 2013; Jokinen et al. 2011; Lisborg 2012; Ollus and Jokinen 2013; Potter and Hamilton 2014; Smit 2011). A recent EU-wide study of severe labor exploitation identified several risk factors contributing to the exploitation of migrant workers. In addition to legal and institutional factors, there are risks relating to the workers' personal situations, to the workplace, and also to conscious actions of employers (FRA 2015).

In discussing the prevention of exploitation of migrant labor, the focus is readily on the employers who exploit the workers. However, the exploitation is not just related to the acts of isolated (criminal) employers but is concentrated in particular industries because of the competitive conditions and structures that shape employment in these industries (Scott et al. 2012). Anderson criticizes the focus on 'bad employers' at the expense of the role of the state in illegalizing workers: attention should instead be paid to how the labor markets and immigration controls illegalize some groups and legalize other groups in particular ways $(2010$, p. 312$)$. The situation of low-waged precarious workers must be analyzed not only in the context of abusive employers, but also in the context of the labor markets within which they work (ibid, p. 313). To understand the exploitation of migrant workers, one should therefore attempt to uncover the structures that enable such exploitation.

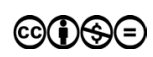




\section{Aims, data, and methods}

This article draws from a research project on the exploitation of migrant labor and trafficking in the cleaning and restaurant sectors in Finland and interviews with various professionals and exploited migrant workers (Ollus and Jokinen 2013). The data consist of interviews with ten migrant workers who had experienced labor exploitation in the cleaning industry, four representatives of cleaning industry employers, seven representatives of labor unions, and one migrant service provider. The interviews were coded and analyzed thematically. ${ }^{2}$ The interviewed migrant workers include eight women from Estonia and Russia and two men from Africa. ${ }^{3}$ All of the interviewed migrant workers had experienced some form of exploitation in the cleaning industry, and a couple of the respondents had been supported by the official system of assistance to victims of trafficking. The exploitation experienced by the workers differed in both length and severity, but all the workers defined their own experiences as exploitative and abusive. The migrant workers had worked for both small and large cleaning companies.

The purpose of the data was to include different voices (employers, employees, authorities, trade unions). This article aims to fill a gap in research by shedding light on how the structural reasons that underpin the exploitation of migrant workers are constructed and seen by the diverse actors involved, but most importantly by the workers themselves. ${ }^{4}$ The interviewed migrant workers give voice to how they experienced the work in the cleaning industry and what kind of exploitation they have experienced. My aim is to link the personal accounts and experiences to the larger context, that is, the practices and structures of the labor market. In doing so, I also aim to link their experiences to the larger contexts of power, ideology, and history (see Young 2011). When combined with the account of the employers and other actors in the labor market, tensions in the labor market can be uncovered, and thus the structures that make the exploitation of migrant workers possible can be analyzed.

\section{Forced flexibility: when labor market flexibility becomes an avenue for exploitation}

Employers acknowledge that there is a problem relating to the available workforce especially for cleaning jobs. The labor force is divided into largely unavailable Finnish workers versus available migrant workers. In practical terms, as is indicated by the interviewed employers and workers alike, cleaning companies want a large pool of flexible labor available at certain, limited hours, for example, early in the morning before stores and offices open, or at night after they close. However, uneven demand and the unattractive working hours (and tasks) limit the number of people able and willing to take these few hours of work.

This way we would get also national labor, if Finns could be offered eight-hour days. There would also be more readiness [to take such jobs]. In terms of our benefit system, if you're offered 2-3 hours, it's perhaps not worth your while to take the job, but if you're offered eight hours, then there would a completely different willingness to work. (Employer's representative 2) 
Both the low salary level and the demand for flexibility have reduced the number of Finnish workers in the cleaning industry (Könönen 2011). Migrant workers seem to increasingly fill this need. The employers' representative cited above also placed some of the blame on the Finnish benefit system. The typical Finnish worker is portrayed as disinterested and even lazy (see Ollus and Jokinen 2013; Könönen 2011), while migrant workers are deemed reliable, flexible, and hard-working. The tension between the views of the employers and the views of the migrant workers is evident in the way that the workers spoke about how their employment in the cleaning industry stemmed from their lack of alternatives, rather than from an active choice (see also Ritari 2013, p. 15).

My boss looked at that paper for a long time and then looked at me. I asked what was the matter. 'You are from a university!' I said, that I was. He asked what I had studied. I said business management. He looked at me with big eyes. (Laughs). But this is how it is. (Migrant worker 2)

Interviewer: Why a cleaner? Didn't you want more...?

-Because of language. You may have graduated from a university, but it's very hard to start there [in Finland]. Many have been teachers and some have even had their own companies; there you still start as a cleaner. (Migrant worker 1)

The interviewed migrant workers embody the result of the dualization of the labor market (Piore 1979), where migrant workers end up in the secondary labor market regardless of their skills or educational background. The migrant workers interviewed seemed to be resigned to the fact that cleaning work is the job they will get, despite their education or aspirations for better employment. That highly educated persons end up in low-skilled work is in stark contrast to the governmental migration and labor policies, which emphasize the need for skilled migrant workers filling professional positions (Ollus and Alvesalo-Kuusi 2012). From the perspective of the migrant workers, the situation is paradoxical. On the one hand, they need any work they can get, but on the other hand, many of the existing labor market practices are disadvantageous, especially for those workers who lack other options. One of the interviewed migrant workers highlights that the demand for flexibility cleverly disguises the migrant workers' position.

Flexibility is not a good word. They call it flexibility, but they are just exploiting the situation. Those people accept it not because they are flexible, it's because they don't have a choice. (Migrant worker 9)

Sassen-Koob points out that migrants are not necessarily cheaper than low-wage national workers, but that it is their powerlessness that makes them profitable (SassenKoob 1981, p. 72). Several of the interviewed workers spoke about employers giving them impossibly large areas to clean and too little time to finish the work, as employers knew that they would not complain. In a capitalist economy, the workers will bear a disproportionate share of the cost of economic flux and uncertainty (Piore 1979). The flip side of flexibility is insecurity (Kalleberg 2003), and migrant workers are likely to bear the heaviest burden of this flux and uncertainty. As the interviewed worker points out above, the migrant workers offer their flexible labor due to a lack of other options. 
Flexibility therefore becomes forced flexibility that builds upon migrant workers' vulnerable position and lack of bargaining power.

\section{Placing the burden on the migrant worker: labor market practices that make exploitation possible}

It is important to emphasize that most of the employers in the cleaning sector are legitimate, organized, and follow the collective agreements that are in force. However, the interviewed workers had experiences of working for both organized and unorganized employers. Problems seem more common among unorganized employers, as also interviewed employers' representatives were eager to point out. Many of the problems in the cleaning industry come down to misuse relating to work contracts and payment of salaries. There are also common and legal practices that are used, which on their own are fully acceptable and legal, but when combined with the lack of negotiating position of migrant workers create a basis for misuse. Instead of offering long-term contracts and regular employment, many cleaning companies-also the large, organized ones-use agency workers or other forms of temporary work (Könönen and Himanen 2011). This article highlights in particular two examples: so-called zero hour contracts and long subcontracting chains. ${ }^{5}$

A 'zero hour contract' refers to a contract by which the employee agrees to work from zero hours per week to a maximum of 37.5 or 40 hours per week. In practice this translates into a 'called to work contract,' where the worker may work full-time one week and not at all the next week. In 2015, Statistics Finland for the first time collected data on zero hour contracts, and found that $4 \%$ of all employees in Finland had such a contract in 2014 (Statistics Finland 2015; the data do not disaggregate information on migrant workers specifically). Such contracts are most common among the youngest workers (ibid.). A study of temporary agency workers found that $16 \%$ of temporary agency workers had a zero hour contract (Huotari and Pitkänen 2013). Contractually zero hour contracts are useful for employers who need a large pool of flexible workers at certain hours, and they are similarly useful for employees who need part-time, flexible work (e.g., students). An employee on a zero hour contract is called to work when needed and the employer only pays for work actually carried out. One employer's representative who was interviewed acknowledged that zero hour contracts may be disadvantageous to workers, but claimed that employees are themselves responsible for what kind of contracts they accept.

Isn't it already a bit stupid of the worker to start to work under such a zero hour contract? I wouldn't dare [to do it] myself if I had a contract like that. I would say that it [the contract] needs to read something else, but can they [the migrant workers] demand thisthat's another question. I don't think it's a problem that such contracts are offered-it's more of a problem if it's not explained what it means. Everyone has the right to decide whether or not they accept such an uncertain contract. If you are not told [about the terms], that's very bad. But you must be told that there are weeks with no hours. Are you going to manage? Calculate and think. (Employer's representative 2)

Although the employer's representative cited above acknowledged that migrant workers may not be properly informed about the contents and consequences of such contracts, 
there seems to be a disregard for the structural factors and powerless position that put workers in a situation where they have no choice but to agree to a disadvantageous contract. As this quote illustrates, the employee is expected to be an active agent, who makes an informed decision when accepting an uncertain contract with possibly poor conditions and too few hours of work (see Ylhäinen 2015). This view disregards the fact that many of the migrant workers cannot challenge their working conditions. ${ }^{6}$ The choice is between employment on poor terms and the possibility of no employment at all. The interviewed migrant workers do cleaning work because they have few other alternatives (see Korsby 2011; Könönen and Himanen 2011, pp. 114-116). Zero hour contracts are hailed by (some) employers and also some workers for their flexibility (Kalleberg 2003; Ojala 2011), but there has been increasing criticism of the conditions of the contracts, which place workers in constant readiness without a guarantee that there actually will be some work. Not all employers find zero hour contracts useful (Lambert 2008), which shows that also within the cleaning industry there are tensions and divergent views regarding the normalized but problematic contractual practices in the sector. One interviewed employer's representative explicitly stated that zero hour contracts are a form of exploitation, based on the insecure and irregular situation they place workers in, and therefore such contracts should not be used. Interviewed trade union representatives highlighted the vicious circle of such contracts: they fulfill an uneven demand for labor that stems from the competition and cost-cutting in the cleaning industry. Trade unions have accordingly engaged in a recent campaign to ban the use of zero hour contracts. A proposal to ban zero hour contracts is currently before Parliament. ${ }^{7}$

There are pros and cons to the zero hour contract, but what is evident is that at worst, the flexibility of the contractual practice can turn into insecurity, instability, and inequality (Lambert 2008). It also may create a negative tie between the employee and the employer, where the full responsibility and consequences of the flexibility are placed on the employee (Davies 2013).

That's precisely the most concrete problem; you either get no hours or if you do, they are given on poor terms. Just like this one guy told me this morning that he had been told to show up at work tomorrow. He has no choice, or of course he always has choices, but it would mean that then there's no need to show up at work at all. (Trade union representative 4 )

Another potentially exploitative practice is the use of subcontractors. Wills sees subcontracted employment as a 'particularly effective way for employers to cut costs, shed responsibility, increase flexibility, and disempower the workforce' (2009, p. 444). The competition in the cleaning industry has also led to a situation where some companies that win tenders subcontract some of the work to other cleaning companies. Long subcontracting chains make possible the creation of situations of misuse or downright exploitation of (migrant) labor. As the interviewed migrant service provider explained, the subcontracting chains mean that less and less money trickle down the chain, combined with more and more work for the workers.

There are clear indications that at worst, workers will carry the burden of the costcutting that the long subcontracting chain entails. This would not be a problem if the workers were in a position where they could demand their rights, or refuse to work. The dependence on their job for subsistence and in many cases for their right to stay in 
the country makes it difficult for them to object. The migrant workers at the end of the subcontracting chain are far from those in power of the 'relationships of subcontracted capitalism' (Wills 2009). Although subcontracting has been a common practice in the cleaning industry for more than 30 years (Bernstein 1986), Koessl sees subcontracting as part of a new employment paradigm that polarizes workers into core and periphery, especially as the cleaners are deprived of any influence over their conditions of work (2012). There is therefore a direct link between subcontracting as a business practice and the precarious situation of migrant cleaning workers (ibid.).

\begin{abstract}
It was so that she [the boss] did subcontracting for a Finn. The Finn got work from the city. The Finn's part was only to take a call from the city and then to call the next person. He did not do any work himself, he checked whether there was money. [...] At the same time you cannot accept an infinite amount of work if you have five to six women. They are not robots who can work 24/7. And then people started to wear out. The summer was terribly hot. Then you are always somewhere inside. You are sweating from morning to evening, you are tired. You do a thorough cleanup job. You are in all that dust. It's hot. And if you ask for a day off, then she [the boss] says, 'Are you joking, get back to work.' (Migrant worker 3)
\end{abstract}

Neither zero hour contracts nor subcontracting chains would be a problem in a labor market where employers abide by the collective agreement and uphold the rights of workers. However, when they are used as a mechanism for demanding labor and reducing rights, it becomes a question of misuse and exploitation. As such, they become practices of the labor market that contribute to the intentional abuse of the labor (especially) of migrant workers.

There are various efforts to counteract the negative effects of long subcontracting chains. The Act on the Contractor's Obligations and Liability when Work is Contracted Out (1233/2006) obliges the contractor to check that the documentation of the subcontractor fulfills certain requirements. However, this only concerns the first level of a subcontracting chain. The contractor is therefore not responsible for problems in subsequent subcontracts. The current law was criticized by one of the interviewed trade union representatives, who wished that the law would cover the whole subcontracting chain. One of the interviewed cleaning company representatives also pointed out the practical problems of oversight:

We often had situations where our foreman found completely unknown people working for us even though we demanded the lists of workers and we had all this guidance for oversight. (Employers' representative 1)

These problems caused this cleaning company to abandon the use of subcontractors altogether. The Real Estate Employers' organization has introduced mandatory identity cards with personal tax numbers for all employees of its member companies as an additional measure to tackle the problem of undeclared work. ${ }^{8}$

Several of the interviewed trade union representatives complained about their lack of deterrents and sanctions against exploitative employers. The unions in Finland have, for example, called for the right to press charges on behalf of exploited or discriminated workers (PAM 2015). Unions are also currently in the process of establishing a joint low-threshold information center for migrant workers (this will be the first of its 
kind in Finland). The SUU and other unions in Finland have, however, been slow to introduce specific immigrant-focused inclusive strategies (Alho 2008; 2012). Unions in Finland still struggle with the questions of solidarity, whose interests they should represent, and who are to be included (Alho 2012; Ristikari 2012). The SUU, which is the main union for cleaning workers, is now placing an increased focus on migrant labor. Currently about $5 \%$ of its members have a migrant background, and the share is growing (PAM 2015). Finland has a high unionization level, but the rate of union membership among migrants and ethnic minorities in Finland is below average (Ristikari 2012, p. 95). According to a study of migrant members of the SUU, only $28 \%$ of the respondents had used any of the services offered by the union (Ritari 2013, p. 22). Although exact data are not available, the majority of those who visit the local SUU office in Helsinki with questions concerning their working conditions are migrant workers (personal communication with a representative of the SUU, 14 December 2015).

\section{The paradox of exploitation: the fear of losing the exploitative employment}

The employment situation of the migrant workers embodies a paradox: the workers fear losing the job in which they are exploited. Several of the migrant workers interviewed said that if they complain about the working conditions or the salary, they risk losing their employment, or they are placed in a less advantageous position compared to those workers who work without complaint.

They told me if I continue kicking back and saying hey I will not do this, I will not do that, then I will not have any extra hours. [...] There are people, those who don't complain about their status, of course they give them more. (Migrant worker 9)

In the long run you see that a person is using you and I could not say anything because then I did not get any work. It was ties like that. (Migrant worker 3)

The lack of options and of bargaining power creates a negative tie between the employee and employer. It has been argued above that there are practices in the current labor market that create conditions for misuse of vulnerable workers, but the experiences of the migrant workers also confirm that there are indeed also employers who intentionally and systematically exploit their (migrant) labor. However, the actions of these employers have to be seen in the context of the migrant workers' more vulnerable position (compared to nationals of the country), as well as in the context of the labor market and its existing controls (or the lack thereof). The vulnerability of migrant workers consists of powerlessness combined with the consequent possibility of using them for undesirable jobs and of exercising considerable control over them (Sassen-Koob 1981). The interviewed migrant workers spoke about various means that employers use to exploit them, including not paying salaries on time to outright threats and direct use of violence. The underpayment of wages is a very common means of keeping migrant workers under the control of the employer (FRA 2015; Jokinen et al. 2011).

If you don't come [to work when the employer demands it at very short notice] he might threaten you like 'if don't come today you will lose your job.' On Saturdays or on Sundays 
he pays a flat rate, not like one and half or times two [as stipulated by the collective agreement]. (Migrant worker 10)

These migrant workers talk about intentional and ongoing practices that increase both the uncertainty and insecurity of the workers. While individual transgressions may not be serious, it is the cumulation of the acts (underpayment of wages, problems with working hours and working areas, lack of possibilities of influencing one's work, etc.) that creates a continuum of acts that may amount to exploitation. A couple of the interviewed workers had experienced more serious forms of exploitation that transgress into trafficking. The exploitation experienced by these workers was serious enough to warrant assistance by the official system of assistance to victims of trafficking. ${ }^{9}$ The exploitation included, for example, being paid very little for their work, working very long hours, living in expensive, overcrowded, and uncomfortable accommodation, often organized by the employer, and being threatened by the employer. While none of the forms of exploitation may on its own seem very serious, it is the totality of the situation, the isolation and the feeling that they have no other alternatives but to submit, that keeps the workers under the control of the employer.

I was paid very little. It was something like 140-200 Euros per month. It is clear that they underpaid, deceived. I even do not know how it can be called life. Just survival. ... Plus, there were no friends, no acquaintances. (Migrant worker 6)

[A representative of the employer] would tell me all the time: 'Don't even try! They will grind you into the dust! You won't even remember your name! Don't even try! He is very powerful!' (Migrant worker 7)

Many of the problematic and exploitative working conditions that migrant workers are facing stem from their dependence on employment to ensure their right to stay in the country. The work permit and the desire to gain permanent residence status is a powerful lever to use against a person who wants to remain in the country. Although most of the interviewed migrant workers had a right to reside in the country, the residence permit forms part of the structures that enable exploitation of migrant workers. Some of the interviewed migrant workers had their residence tied to having employment (those from non-EU countries as well as noncitizens from Estonia). They were therefore ready to endure difficult working conditions and were afraid to complain, since they feared losing their job and thus their right to remain in the country (see Könönen 2012). ${ }^{10}$

Many of these [problems] are related to the authorities and their way of treating the populations, which then are trapping people in difficult situations. We have not been talking only about employers mistreating people, but the system mistreating people. Sometimes they work together, the system and the abusing employers. (Migrant service provider)

As has been pointed out elsewhere (Anderson 2010; Könönen 2012) migration regimes themselves create situations that expose and exploit the most vulnerable. Exploited migrant workers are therefore exposed not only to abusive employers, but also to abusive employers in combination with labor market practices and an immigration regime that make it possible for exploitation to happen. 


\section{Conclusions: Forced flexibility and the cumulation of exploitation}

Based on interviews with migrant workers, employers, and trade union representatives in the cleaning industry in Finland, this article has examined the negative effects of recent changes in the labor markets. Globalization with the related increased competition between countries and companies, outsourcing, and demands for greater flexibility have led to major changes in the nature of work. These changes have affected the workforce and especially those who are the most vulnerable and have the least options and alternatives: migrant workers. The cleaning industry is one example of a labor market where the conditions of work have been particularly influenced by forces of globalization and what may be defined as neoliberal policies.

This article has three main findings. Firstly, the demand for labor flexibility exploits the vulnerable position of migrant workers, because they have limited options other than to agree to working on poor and exploitative terms. There are serious downsides to flexibility although especially employers consider flexibility in the labor market a necessity. I argue that migrant workers end up in situations of forced flexibility where their lack of options becomes masked as flexibility: a willingness to take any job on any terms. Forced flexibility is based on the migrant workers' lack of bargaining power and is therefore one-sided. It places the burden and risk on the employee, while giving the options and decision-making power to the employer. Flexibility may be a necessity and useful for some groups of workers. In a labor market that upholds basic rights and standards, the drawbacks of flexibility should be borne by both parties and it should not be used as a means of exploitation (Gray 2004).

Secondly, the article has pointed to exploitation that stems from a change in the type of contractual practices in the cleaning industry. Zero hour contracts and subcontracting chains are examples of contractual practices that are approved and upheld by the State. As long as employees are in a position to choose whether they undertake work under such terms, these contractual practices are not problematic. However, when they are used as a means of placing the risk of flexibility on the employee, or as a means of demanding work, they become forms of misuse. Such practices therefore become structures of the labor market that contribute to the intentional abuse of the labor of (especially) migrant workers. Because migrants are among the chief victims of the weakened welfare state and deregulated labor markets (Castles 2011; Lillie and Greer 2007), it is clear that migrant workers are also disproportionately affected by the negative effects of structural changes in the labor markets.

Zero hour contracts and subcontracting schemes may be accepted and normalized practices in the labor market, but at the same time they disproportionately affect those who already are the most vulnerable. While it can be questioned whether the misuses of migrant labor are just the transgressions of individual, isolated 'bad employers' (Anderson 2010), research shows that misuse and exploitation do take place especially in employment situations that can be described as precarious and poor (Standing 2011). It is not the entry of migrants into the labor market that creates low-paid, unattractive jobs. Instead, migrant workers tend to end up in employment positions that are already poor and where there is need for labor (Könönen 2012). I argue that the exploitation of migrant labor is not (solely) an act of individual 'bad employers,' but a structural practice that is directly related to the changes that have taken place in the labor market. As such, the exploitation of migrant labor is not a question of single, 
isolated acts, but a structural problem related to both labor market and immigration practices.

The mismatch between the existing labor standards and the actual practices of cleaning companies as experienced by the interviewed migrant workers is an example of the new discourses in the labor market as highlighted also by Ylhäinen (2015). Although perhaps not 'neoliberal' as such, there are visible and gradual changes in Finnish labor market practices that allow for a 'flexibilization' of contracts and employment practices (Julkunen 2008). The traditional tripartite structure of agreement in the Finnish labor market is being challenged as a result of the economic recession and the rigidity of the bargaining structure (OECD 2016). At the time of writing, representatives of employers and trade unions had negotiated for almost a year in an effort to reach agreement on a 'social contract' aimed at cutting labor costs in an effort to improve the Finnish economy. Should the parties not find agreement, the Government might unilaterally impose its own labor reforms, including cuts to salaries and benefits, thus intervening in areas that have traditionally been dealt with under the tripartite structure. ${ }^{11}$

Thirdly, the article has shown that the employment situation of the migrant workers embodies a paradox because the workers fear losing the job in which they are exploited. If the workers complain about the working conditions or the salary, they risk losing their employment, or they are placed in a less advantageous position compared to those workers who work without complaint. The cumulative use of coercion in the exploitation of migrant workers is difficult to ascertain because many of the forms of coercion take place at the same time, as a chain of events, starting with deception, followed by wage manipulation, threats of denunciation, and direct violence (Andrees 2008, p. 22). Speaking of a continuum of exploitation (Andrees 2008; Kelly 2007; Long 2004; Skrivankova 2010) helps to conceptualize the experiences of migrant workers not as individual, isolated incidents, but as part of a larger context. A parallel can be drawn to the phenomenon of sexual violence against women. Kelly argues that sexual violence can be seen as a continuum, where the power structure between men and women plays out through 'routine' use of aggression against women as well as through more serious, nonroutine forms of male violence against women (Kelly 1988). I argue that the experiences of migrant workers can similarly be described as 'routine' maltreatment by the employer. Because of the power imbalance between the migrant workers and their employers, also the less serious forms of exploitation form part of a larger continuum of both extent and range (see Kelly 1988, p. 75). Therefore, the single actions of 'bad employers' who intentionally exploit migrant workers cannot be treated as isolated phenomena. Instead, they point to a more structural problem having to do with the migrants' position in the labor market. If addressed in isolation, the individual acts of exploitation that migrant workers have experienced do not point to any larger problem. However, when placed along the continuum and in the context of a cumulation of exploitation, they describe a trend. In the context of the continuum, the personal experiences of exploitation that migrant workers have experienced can be seen to reflect a structural practice. As such, the personal experiences of individuals become part of a larger societal problem of exploitation (see Young 2011).

This article has showed that migrant workers in the cleaning industry do experience exploitation. The findings are similar to other studies that have looked at the precariousness of migrant workers in Finland (e.g., Könönen 2012; Könönen and Himanen 2011; Sams and Sorjanen 2015). This article argues that there exists a link between less and 
more serious forms of exploitation. Although the experience of all of the interviewed migrant workers may not constitute human trafficking, their experiences can be placed along the same continuum. Some of the interviewed migrant workers had experienced serious exploitation that could be defined as trafficking. Their experiences were not hugely different from that of other workers, and took place in a similar context as the exploitation of the other workers. What I have attempted to show is that labor market practices that utilize the lack of bargaining power of the most vulnerable workers may facilitate exploitation that eventually leads to forced labor and human trafficking. Exploitation of migrant workers-at least in the Finnish cleaning industry, and with the sample of interviewed migrant workers presented here-is directly linked to the results of major changes in the labor market. As such, modern forms of forced labor arise from existing practices in the (neoliberal) labor market.

There seems to be a tolerance for abuse of (migrant) workers when States, business, and consumers all benefit from cheap goods and services. It is this tolerance that allows exploitation of migrant workers, and ultimately trafficking for forced labor, to continue. The recent EU-wide study of severe forms of labor exploitation in the European Union found that at the macro level, it is the large global economic disparities combined with increasing global mobility that drive people to move from one country to another to find work (FRA 2015). Many migrant workers reason that any work is better than no work, especially when their salary is better than in the country they come from, despite the exploitation that they endure. Even highly regulated labor markets have trouble preventing exploitation of migrant labor and the undercutting of working conditions, and less regulated labor markets will be even less likely to do so (Refslund 2014). Exploitation and trafficking can therefore only truly be prevented by diminishing inequalities both globally and locally. In the interim, we need to make visible and address the practices and structures in our labor market that exploit the vulnerabilities of migrant workers. The number of people migrating for work or other purposes is not going to decrease in the near future, as is also shown by the recent refugee crisis in Europe. We therefore need to ensure decent labor conditions for all, including for those who are the most vulnerable.

\section{References}

Abbasian, S. and Hellgren, C. (2012) Working conditions for female and immigrant cleaners in Stockholm County. An intersectional approach, Nordic Journal of Working Life Studies 2(3): 161-181. doi: http://dx.doi.org/10.19154/njwls.v2i3.2369.

Alho, R. (2008) Maahanmuuttajat suomalaisessa ay-liikkeessä-tapaus PAM (Migrants in the Finnish trade union movement-the case of SUU). In: Helander, M. (ed.) Going Global. Ay-likkeen menestysresepti globaalissa ajassa? (Going Global. The Road to Success for the Trade Union Movement in the Global Era?) Minerva.

Alho, R. (2012) Maahanmuutto ja maahanmuuttajat—uhka vai mahdollisuus ammattiliitoille? (Immigration and migrants-a threat or a chance for trade unions?) In: Helander, M. and Nylund, M. (eds.) Palkka työstä. AY-liike ja edunvalvonnan undet muodot (Pay for Work. The Trade Union and the New Forms of Promotion of Interests) Into.

Allamby, L., Bell, J., Hamilton, J., Hansson, U., Jarman, N., Potter, M. and Toma, S. (2011) Forced Labor in Northern Ireland: Exploiting Vulnerability. Joseph Rowntree Foundation. 
Anderson, B. (2010) Migration, immigration controls and the fashioning of precarious workers, Work, Employment \& Society 24(2): 300-317. doi: http://dx.doi. org/10.1177/0950017010362141.

Andrees, B. (2008) Forced Labour and Trafficking in Europe: How People Are Trapped In, Live Through and Come Out. Working Paper, Special Action Programme to Combat Forced Labour. ILO.

Anti-Slavery International (2006) Trafficking for Forced Labour in Europe. Report on a Study in the UK, Ireland, the Czech Republic and Portugal. London: Anti-Slavery International.

Beck, U. (2000) The Brave New World of Work. Cambridge: Polity Press.

Bernstein, D. (1986) The subcontracting of cleaning work: a case in the casualization of labor, Sociological Review 34(2): 396-422. doi: http://dx.doi.org/10.1111/j.1467-954X.1986. tb02708.x.

Böckerman, P. and Kiander, J. (2006) Talouspolitiikka (Economic policy). In: Saari, J. (ed.) Suomen malli. Murroksesta menestykseen? (The Finnish Model. From Rupture to Success?) Yliopistopaino.

Castles, S. (2011) Migration, crisis and the global labour market, Globalizations 8(3): 311-324. doi: http://dx.doi.org/10.1080/14747731.2011.576847.

Clark, N. (2013). Detecting and Tackling Forced Labour in Europe. York: Joseph Rowntree Foundation.

David, F. (2010) Labour Trafficking. Australian Institute of Criminology, Research and Public Policy Series no. 108. Canberra: AIC.

Davies, S. (2013) Zero-hours Contracts, Global Labour Column No. 152, October 2013. Corporate Strategy and Industrial Development, University of the Witwatersrand.

Forsander, A. (2013) Maahanmuuttajien sijoittuminen työelämään (The placement of migrants in working life). In Martikainen, T., et al. (eds.) Muuttajat. Kansainvälinen muuttoliike ja suomalainen yhteiskunta (International Migration and Finnish Society) Gaudeamus.

FRA (2015) Severe labor exploitation: workers moving within or into the European Union. States' obligations and victims' rights. European Union Agency for Fundamental Rights.

Geddes, A., Craig, G. and Scott, S. with Ackers, L., Robinson, O. and Scullion, D. (2013) Forced Labour in the UK. Joseph Rowntree Foundation.

Gomberg-Muñoz, R. (2010) Willing to work: agency and vulnerability in an undocumented immigrant network, American Anthropologist 112(2): 295-307. doi: http://dx.doi. org/10.1111/j.1548-1433.2010.01227.x.

Gray, A. (2004) Unsocial Europe: Social Protection or Flexploitation? London: Pluto Press.

Herod, A. and Aguiar, L. L. M. (2006) Introduction: geographies of neoliberalism. In Aguiar, L. L. M. and Herod, A. (eds.) The Dirty Work of Neoliberalism: Cleaners in the Global Economy. Wiley-Blackwell. doi: http://dx.doi.org/10.1002/9781444397406.ch1.

Honkatukia, P. (2011) Heikoimpien asialla? Rikosten uhrien parissa työskentelevien näkemyksiä haavoittuvuudesta (On behalf of the most vulnerable? Views on vulnerability among those working with crime victims), Oikeus 20(2): 199-217.

Houseman, S. N. (2001) Why employers use flexible staffing arrangements: evidence from an establishment survey, Industrial and Labor Relations Review 55(1): 149-170. doi: http://dx.doi.org/10.2307/2696191.

Huotari, K. and Pitkänen, S. (2013) Selvitys määräaikaisten sopimusten yleisyydestä ja tiedottamisesta vuokratyössä (A study on the prevalence of temporary contracts and the provision of information in agency work). Työ- ja elinkeinoministeriön julkaisuja, työ ja yrittäjyys, 16/2013. Työ- ja elinkeinoministeriö.

Jokinen, A., Ollus, N. and Viuhko, M. (2011). Work on any terms: trafficking for forced labour and exploitation of migrant workers in Finland. In Jokinen, A., Ollus, N. and 
Aromaa, K. (eds.) Trafficking for Forced Labour and Labour Exploitation in Finland, Poland and Estonia. Publication series 68. HEUNI, pp. 31-164.

Julkunen, R. (2003) Hiipivä ja ryömivä-pääoma valtaamassa hyvinvointivaltiota? (Creeping and crawling-is capital invading the welfare state?) In: Melin, H. and Nikula, J. (eds.) Yhteiskunnallinen murros (The Societal Rupture). Vastapaino.

Julkunen, R. (2008) Uuden työn paradoksit. Keskusteluja 2000-luvun työprosesseista (The paradoxes of the new work. Discussions on the work processes of the 2000's) Vastapaino.

Jutila, M. (2011) Narrowing of public responsibility in Finland 1990-2010, Social Policy \& Administration 45(2): 194-205. doi: http://dx.doi.org/10.1111/j.1467-9515.2010.00764.x.

Kalleberg, A. L. (2003) Flexible firms and labor market segmentation. Effects of workplace restructuring on jobs and workers, Work and Occupations 30(2): 154-175. doi: http://dx.doi.org/10.1177/0730888403251683.

Kantola, A. (2015) Muuttuuko maan tapa? Miten Suomessa käytetään talouspoliittista valtaa (Will the customary practice in the country change? How economic political power is used in Finland) SITRA.

Kelly, L. (1988) Surviving Sexual Violence. Cambridge: Polity Press.

Kelly, L. (2007) A conducive context: trafficking in persons in Central Asia. In Lee, M. (ed.) Human Trafficking. Cullompton: Willan Publishing, pp. 73-91.

Kettunen, P. (2012) Reinterpreting the historicity of the Nordic model, Nordic Journal of Working Life Studies 2(4): 21-43. doi: http://dx.doi.org/10.19154/njwls.v2i4.2303.

Koessl, G. (2012) Precariousness and futurity: the example of subcontracted cleaning workers in the banking and finance industry in London, Graduate Journal of Social Science 9(2): 86-108.

Korsby, T. M. (2011) Menneskehandel i rengøringsbranchen? En kvalitativ undersøgelse af migrations- og arbejdsvilkårene for en gruppe migrantarbejdere $i$ Danmark (Human trafficking in the cleaning industry? A qualitative study of migration and employment terms among a group of migrant workers in Denmark). Center mod menneskehandel. Socialstyrelsen.

Kyntäjä, E. (2011) Viron- ja venäjänkielisten maahanmuuttajien kokemukset työyhteisön ja ammattiliiton jäsenenä (The experiences of Estonian and Russian speaking migrants as members of the working community and trade unions). In: Helander, M. (ed.) Totta toinen puoli? Työperäisen maahanmuuton todelliset ja kuvitellut kipupisteet (Partly True? The Real and Imagined Problems of Labor Immigration) SSKH Skrifter 31.

Könönen, J. (2011) Palvelualan työnantajat ja joustavat ulkomaalaiset työntekijät. Maahanmuuttohallinnon merkitys prekaarin työvoiman tuottamisessa (Employers in the service sector and flexible foreign workers. The role of migration administration in producing precarious labor), Janus 19(1): 52-67.

Könönen, J. (2012) Prekaari työvoima ja työn hierarkiat metropolissa. Ulkomaalaiset matalapalkkaisilla palvelualoilla (Precarious labor and the hierarchies of employment in the metropolis. Foreigners in low-paid service industries), Sosiologia 49(3): 190-205.

Könönen, J. and Himanen, M. (2011) Prekaarisuuden tuotanto -turvapaikanhakijoiden kokemuksia työstä (The production of precarity—asylum seekers' experiences of work). In: Helander, M. (ed.) Totta toinen puoli? Työperäisen maahanmunton todelliset ja kuvitellut kipupisteet (Partly True? The Real and Imagined Problems of Labor Immigration) SSKH Skrifter 31.

Lambert, S. J. (2008) Passing the buck: labor flexibility practices that transfer risk onto hourly workers, Human Relations 61(9): 1203-1227. doi: http://dx.doi.org/ $10.1177 / 0018726708094910$.

Lillie, N. and Greer, I. (2007) Industrial relations, migration, and neoliberal policies: the case of the European construction sector, Politics \& Society 35(4): 551-581. doi: http://dx.doi.org/10.1177/0032329207308179. 
Lisborg, A. (2012) Human Trafficking for Forced Labour in Denmark? The Danish National Board of Social Services.

Lith, P. (2012) Kiinteistöala Suomen kansantaloudessa. Muistio kiinteistöalan yritystoiminnasta, markkinoista ja kehityslinjoista 2010-11 (The real estate industry in the Finnish economy. A memorandum on business, markets and developments in the real estate industry 2010-11). Suunnittelu- ja tutkimuspalvelut Pekka Lith, Helsinki, 7 January 2012.

Long, L. D. (2004). Anthropological perspectives on the trafficking of women for sexual exploitation, International Migration 42(1): 5-31. doi: http://dx.doi.org/10.1111/j.00207985.2004.00272.x.

Myrskylä, P. and Pyykkönen, T. (2015) Tulevaisuuden tekijät-Suomi ei pärjää ilman maahanmunttoa (The makers of the future-Finland will not manage without immigration). Elinkeinoelämän Valtuuskunta EVA Analyysi 42.

Nuutila, A.-M. and Melander, S. (2008) RL 47 luku. Työrikokset (Criminal Code, Chapter 47. Labor crimes). In: Lappi-Seppälä, T., Hakamies, K., Koskinen, P., Majanen, M., Melander, S., Nuotio, K., Nuutila, A.-M., Ojala, T. and Rautio, I. (eds.) Rikosoikeus. Oikeuden perusteokset (Criminal Law. The Principal Works of Law) WSOY.

OECD (2016). OECD Economic Surveys Finland. January 2016 overview. http://www.oecd. org/eco/surveys/Overview-OECD-Finland-2016.pdf

Ojala, S. (2011) Supplemental work at home among Finnish wage earners: involuntary overtime or taking the advantage of flexibility? Nordic Journal of Working Life Studies 1(2): 77-97. doi: http://dx.doi.org/10.19154/njwls.v1i2.2346.

Ollus, N. and Alvesalo-Kuusi, A. (2012). From cherry-picking to control: migrant labour and its exploitation in Finnish governmental policies, Nordisk Tidsskrift for Kriminalvidenskab 99(3): 376-398.

Ollus, N. and Jokinen, A. (2013). 'We've got people lined up behind the door': Placing the trafficking and exploitation of migrant workers in context in the restaurant and cleaning sectors in Finland. In Ollus, N., Jokinen, A. and Joutsen, M. (eds.) Exploitation of Migrant Workers in Finland, Sweden, Estonia and Lithuania. Uncovering the Links between Recruitment, Irregular Employment Practices and Labor Trafficking. Publication Series No. 75. HEUNI.

Öhrling, T. (2014) Increased participation among cleaners as a strategy to improve quality and occupational health, Nordic Journal of Working Life Studies 4(3): 79-98. doi: http://dx.doi.org/10.19154/njwls.v4i3.4181.

PAM (2015). Maahanmuuttopoliittinen objelma 2015-2019 (The migration policy for 2015-2019) Palvelualojen ammattiliitto (Service Union United).

Patomäki, H. (2007). Uusliberalismi Suomessa. Lybyt historia ja tulevaisunden vaibtoehdot. (Neoliberalism in Finland. A brief history and alternatives for the future) Yliopistopaino.

Piore, M. J. (1979) Birds of Passage. Migrant Labor and Industrial Societies. Cambridge: Cambridge University Press.

Potter, M. and Hamilton, J. (2014) Picking on vulnerable migrants: precarity and the mushroom industry in Northern Ireland, Work, Employment \& Society 28(3): 390-406. doi: http://dx.doi.org/10.1177/0950017013510760.

Refslund, B. (2014) Intra-European labor migration and deteriorating employment relations in Danish cleaning and agriculture: industrial relations under pressure from EU8/2 labor inflows? Economic and Industrial Democracy 31 October 2014 (published online): 1-25.

Riihinen, O. (2011) Keskiluokkaistuva ja eriarvoistuva Suomi-hyvinvointivaltio koetuksella (Finland is becoming more middle class and segregated and the welfare state is being tested). In: Palola, E. and Karjalainen, V. (eds.) Sosiaalipolitiikka-Hukassa vai uuden jäljillä? (Social Policy-Lost or Finding Something New?) THL.

Ristikari, T. (2012) Finnish Trade Unions and Immigrant Labour. Migration Studies C 22. Institute of Migration. 
Ritari. A. (2013) Töissä Suomessa. Raportti Palvelualojen ammattiliiton maahanmuuttajajäsenten kokemuksista (Working in Finland. A report on the experiences of the migrant members of the Service Union United) PAM.

Roth, V. (2010) Ihmiskaupasta suomalaisessa työelämässä (On human trafficking in Finnish working life), Oikeus 39(3): 278-287.

Ryan, S. and Herod, A. (2006) Restructuring the architecture of state regulation in the Australian and Aotearoa/New Zealand cleaning industries and the growth of precarious employment, Antipode 38(3): 486-507. doi: http://dx.doi.org/10.1111/j.00664812.2006.00591.x.

Sams, A. and Sorjanen, A.-M. (2015) Finland. Social Fieldwork Research (FRANET). Severe Forms of Labour Exploitation. Supporting Victims of Severe Forms of Labor Exploitation in Having Access to Justice in EU Member States. European Union Agency for Fundamental Rights (FRA).

Sassen-Koob, S. (1981) Towards a conceptualization of immigrant labor, Social Problems 29(1): 65-85. doi: http://dx.doi.org/10.2307/800079.

Scott, S., Craig, G. and Geddes, A. (2012). Experiences of Forced Labour in the UK Food Industry. Joseph Rowntree Foundation.

Seifert, A. M. and Messing, K. (2006) Cleaning up after globalization: an ergonomic analysis of work activity of hotel cleaners, Antipode 38(3): 557-578.

Sennett, R. (1998) The Corrosion of Character. The Personal Consequences of Work in the New Capitalism. New York \& London: Norton.

Skrivankova, K. (2010). Between Decent Work and Forced Labour: Examining the Continuum of Exploitation. JRF programme paper: Forced Labour. Joseph Rowntree Foundation.

Smit, M. (2011) Trafficking in human beings for labor exploitation. The case of the Netherlands, Trends in Organised Crime 14(2): 184-197. doi: http://dx.doi.org/10.1007/ s12117-011-9123-3.

Standing, G. (2011) The Precariat. The New Dangerous Class. Bloomsbury.

Statistics Finland (2015) Labour Force Survey 2014. Employees' zero-hour contracts. Official Statistics of Finland, Labour market 2015.

Stone, K. V. W. (2005) Flexibilization, Globalization, and Privatization: Three Challenges to Labor Rights in Our Time, Osgoode Hall Law Journal Fall 2005, UCLA School of Law Research Paper No. 05-19.

Sutela, H. (2015) Ulkomaalaistaustaiset työelämässä (Foreign-born in working life). In Nieminen, T., Sutela, H. and Hannula, U. (eds.) Ulkomaista syntyperää olevien työ ja hyvinvointi Suomessa 2014 (The Work and Welfare of Those with a Foreign Origin in Finland in 2014) Tilastokeskus.

Tarkkonen, J. (2010) Enemmän, nopeammin ja halvemmalla. Laadullinen tutkimus siivoojien kohtelusta, asemasta, vaikutus-mahdollisunksista ja työoloista siivousyrityksissä ja julkisissa organisaatioissa (More, quicker, and cheaper. A qualitative study of the treatment, status, influence and working conditions of cleaners in cleaning companies and public organisations) Innosafe- tutkimukset 1/2010. Oulu.

UNODC (2014) Global Report on Trafficking in Persons 2014. United Nations.

Verohallinto (Tax Administration) (2013). Siivouspalvelualan yritykset (Cleaning companies). Harmaan talouden selvitysyksikkö, 21 May 2013.

Wills, J. (2009) Subcontracted employment and its challenge to labor, Labor Studies Journal 34(4): 441-460. doi: http://dx.doi.org/10.1177/0160449X08324740.

Ylhäinen, M. (2015) Työoikeus ja prekaari ybteiskunta (Labour law and the precarious society) FORUM IURIS.

Young, J. (2011) The Criminological Imagination. Cambridge: Polity Press. 


\section{End Notes}

1 The data include migrant workers, but do not disaggregate based on whether a person has a migrant background or not. According to the Service Union United, atypical contracts are presumed to be more common among migrant workers, but there is no research on the prevalence of such contracts (personal communication).

2 The interviews were conducted in 2013 as part of a research component in a EU-funded project, and therefore the topics covered in the interviews were broader than the themes covered in this article. All of the migrants had contacted some form of service provider (a trade union, the labor inspectorate, or a nongovernmental organization) or had received help from the official system of assistance to victims of trafficking in Finland. The interviewed workers represent a specific group of workers, that is, those who had sought and received help. This may be one of the major weaknesses of the data: it does not include those who did not seek help, but who might potentially be the most vulnerable and most exploited.

3 Some of the migrant workers were EU citizens while others were so-called third country nationals. All of the workers had a legal permit or other legal grounds for staying in the country at the time they worked in the cleaning industry in Finland. For the purposes of this article, the workers have not been divided or compared on the basis of their background or immigration status. Even though labor exploitation and sexual exploitation may overlap, and exploitation therefore may have gendered implications (see UNODC 2014 for recent global trends), the gender of the interviewees is not emphasized in this article. One of the interviewees spoke about her experiences of sexual harassment and sexual exploitation at work, but the gendered nature of exploitation was not included as a specific question to interviewees. This is clearly an area where further research is needed.

${ }^{4}$ Although several trade union representatives were interviewed, this article does not analyze in detail the views and roles of trade unions vis-à-vis immigration. This has instead been discussed in a number of other studies (e.g., Alho 2008; 2012; Kyntäjä 2011; Ristikari 2012).

5 There are many other problematic practices that are not covered here, including the use of posted labor or forced self-employment.

${ }^{6}$ It is important to highlight that the migrant workers are not solely vulnerable and without means of resistance. At the time of the interview, the interviewed workers were no longer exploited at work and had all sought and/or received assistance, thus showing that they had eventually stood up to the employers (albeit losing their job as a result).

7 See yle.fi/uutiset/citizens_initiative_opposing_zero-hour_contracts_to_go_before_mps/ 7977791.

8 See http://www.kiinteistotyonantajat.fi/tietoaliitosta/eettisetohjeet/. Such personal identity cards are mandatory by law (1231/2011) in the construction sector.

9 The official system of assistance is managed by the Ministry of Interior, see http://www. humantrafficking.fi/in_english.

10 In Finland a work permit is granted for one year initially, followed by four years. In order to receive the first permit, the person must first find work, and then apply for the permit. The extension permit is dependent on whether the migrant worker earns enough to cover a certain minimum threshold, and whether certain terms of employment are met. Most work permits are sector-specific rather than tied to a specific employer.

11 See http://yle.fi/uutiset/government accepts social contract/8715226; http://yle.fi/uutiset/ pm_sipila_puts_labour_legislation_on_ice/8638429; www.eurofound.europa.eu/observatories/eurwork/articles/labour-market-industrial-relations-business/finland-new-government-challenges-tradition-of-tripartite-consensus. 